ИЗВЕСТНЯ АКАДЕМИИ НАУК ЭСТОНСКОП ССР. ТОМ 27

ГЕОлогия. 1978, $\mathrm{Ni} 2$

\title{
ОПЫТ ИСПОЛЬЗОВАНИЯ ТЕЛЕВИЗИОННЫХ КОСМИЧЕСКИХ СНИМКОВ ДЛЯ ИЗУЧЕНИЯ УСЛОВИЙ ФОРМИРОВАНИЯ ЛЕДНИКОВЫХ ОТЛОЖЕНИЙ В ПРИБАЛТИКЕ
}

В целях увеличения объема геологической информации и повышения ее достоверности наряду с аэрофотоснимками (изображением Земли в видимом диапазоне) широко применяются аэросъемки в радиоволновом и тепловом диапазонах, съемки из космоса и т. д. Снимки Земли из космоса имеют большие преимущества перед другими материалами благодаря повышенной обзорности: одним кадром охватывается площадь в десятки и даже сотни тысяч квадратных километров.

По способу получения снимки из космоса делятся на фотографические и телевизионные. В нашем сообщении использованы только телевизионные оптические снимки, которые получаются следующим образом: на спутнике изображение земной поверхности фокусируется через объектив съемочного аппарата на экран, построчно считывается с него электронным лучом, преобразуется в электрические сигналы и передается на Землю. Здесь изображение восстанавливается на фотоматериале. Размеры различимых на таких снимках объектов в природе составляют не менее 1250 м. Однако, несмотря на это, телевизионные снимки из космоса успешно применяются для региональных геологических, преимущественно тектонических построений (Григорьев, 1970; Башилова, 1973; Башилова и др., 1973 а, б; Астахов, Ероменко, 1974; и т. д.).

Нами проанализировано несколько телевизионных оптических снимков с ИСЗ «Метеор» с изображением территории Северо-Запада европейской части СССР. Исходный масштаб порядка 1:7000000$1: 10000000$. Снимки были сделаны в феврале-марте 1972 г. и мае 1974 г. в видимой области спектра. Качество большинства из них удовлетворительное, в ряде случаев плохое из-за почти сплошной облачности. Однако даже эти материалы позволяют положительно решить ряд задач, связанных с изучением условий формирования ледниковых отложений, в частности, определить мощность плейстоценовых образований, неровности поверхности коренных пород, структуру коренных пород (в первую очередь наличие разрывных нарушений), динамику ледниковых потоков.

Участки распространения ледниковых отложений повышенной мощности проявляются на телевизионных снимках по-разному. Для них характерны два типа изображения.

Во-первых, светлый тон, сложный рисунок, нечеткие границы. Это присуще без исключения всем возвышенностям: Пандивереской, Отепя- 
ской, Хааньяской, Видземской, Латгальской, Курземской, Жямайтской, Лемболовской. Минимальную мощность ледниковых отложений, которым соответствует светлый тон изображения, предстоит еще определить. По нашим материалам, она должна составлять первые десятки метров (вероятно, не менее $20-30$ м). Во всяком случае центральные части возвышенностей, где мощность рыхлых отложений меньше, передаются изображением более светлого тона (Курземская, Сакалаская). По-видимому, это обусловлено и тем, что бо́льшая часть возвышенностей хозяйственно освоена и лишена древесного покрова.

Во-вторых, темный тон, ровный рисунок, четкие границы. Такое изображение получено для нескольких участков на берегу Балтийского моря в районе г. Лиепая и от пос. Павилоста до устья р. Венты. Здесь мощность четвертичных отложений превышает $50 \mathrm{\mu}$. Изолированность таких участков связана, по-видимому, с древними дочетвертичными долинами, выявленными по данным бурения. Днища их располагаются ниже отметок -50 м. Это в какой-то мере отражается и на современном ландшафте. Небольшие по площади светлые участки, смежные с описанными и разделяющие их, соответствуют, вероятно, древним водоразделам. Такую интерпретацию телевизионного изображения Балтийского побережья желательно проверить с привлечением первичного фактического материала. С учетом результатов дешифрирования изопахиты четвертичных отложений следует проводить на картах не параллельно берегу Балтики, как это практикуется иногда, а в соответствии с планом древней гидрографической сети.

Поскольку более значительные толщи ледниковых отложений наблюдаются во впадинах рельефа поверхности дочетвертичных пород, то отмеченные выше дешифровочные признаки участков четвертичных отложений повышенной мощности позволяют опознавать и понижения дочетвертичного рельефа. Так, унаследованные от дочетвертичного рельефа котловина оз. Выртсъярв и Рижско-Елгавская низина на снимках затемнены по сравнению с соседними участками. Аналогично запечатлено и понижение поверхности дочетвертичных пород в районе устьев рек Наровы, Луги, Плюссы.

Спрямленные элементы любого аэро- или космического изображения обычно интерпретируются как разрывные нарушения (это не обязательно один разлом со смещением, но и зоны дробления, и трещины без смещения). На всех снимках такие линеаменты образуют преимущественно две системы - северо-восточную и северо-западную. На некоторых снимках, полученных в разное время, одни и те же линеаменты повторяются, например, восточнее оз. Выртсъярв, в районе Лиепая, Чудского и Псковского озер, в устье р. Немана и т. д. Для уверенного отождествления этих линеаментов с разрывными нарушениями следует привлечь все имеющиеся геологические и географические материалы. При этом необходима особая тщательность, поскольку речь идет о выявлении совсем новых, ранее неизвестных элементов структуры осадочного чехла. В отдельных случаях линеаменты, дешифрованные по телевизионным снимкам, совпадают с ранее известными нарушениями, например, с уступом, отделяющим Курземский выступ от Тельшайской ступени, с параллельными западно-северо-западными нарушениями в низовье р. Немана, с разломом на западном берегу Ладожского озера и др. Приведенные данные свидетельствуют о целесообразности использования телевизионных снимков для изучения условий формирования четвертичных толщ, поскольку известны примеры активного влияния разрывных нарушений на ход осадконакопления в плейстоцене. Так, Западно- 
Ладожский новейшнй прогнб, ограниченный с запада разломом, который установлен бурением и четко видим на телевизионных снимках, характеризуется увеличенной (до $175 \mathrm{M}$ ) мощностью четвертичных отложений, преимущественно принадлежащих московскому оледенению (Усикова и др., 1970).

С точки зрения изучения динамнки ледниковых потоков особый интерес представляют телевизионные изображения Отепяской, Хааньяской, Видземской и Латгальской возвышенностей. На снимках видно, что светлые участки изображения, соответствующие скоплениям ледниковых отложений значительной мощности, и разделяющие их небольшие по площади участки относительно темного тона (такие понижения современного рельефа, как долины рек Педедзе, Айвиексте, низина оз. Лубана) образуют серию расходящихся дуг. При этом дуги выпуклостью обращены на юго-восток, сближаются на северо-востоке - в направлении Псковского озера и расходятся к западу. Отчетливо видно, что долина р. Великой отделяет скопления ледниковых образований Хааньяской, Видземской и Латгальской возвышенностей от расположенных восточнее Судомской и Бежаницкой. Рнсунок телевизионного изображения к востоку от р. Великой и Псковского и Чудского озер совсем иной, чем к западу от них. Латгальская и восточная часть Хааньяской возвышенности (к востоку от р. Педедзе) представляют собой единую дугу, в то время как остальная часть Хааньяской и Видземская возвышенность образуют другую, отделенную от первой рядом понижений. По-видимому, описанные скопления ледниковых отложений следует рассматривать как краевые образования ледникового потока.

Итак, из анализа телевизионных изображений можно сделать следующие палеогеографические выводы относительно условий формирования четвертичных отложений Прибалтики.

1. На изученном участке четко фиксируются два этапа отступания ледника. На раннем этапе сформировались восточная часть Хааньяской и Латгальская возвышенность. Формирование последней происходило, по-видимому, в несколько стадий, поскольку она состоит из ряда дуг краевых образований, примыкающих друг к другу (рисунок). На позднем этапе морфологически окончательно оформились Хааньяская и Видземская возвышенности.

2. Наличие депрессии р. Великой и характер расположения гряд краевых образований к западу от нее свидетельствуют о том, что Хааньяская, Видземская и Латгальская возвышенности обязаны своим происхождением только ледниковому потоку Рижского залива, другие же потоки (Чудско-Псковский и Ладожско-Ильменский) в их формировании участия не принимали.

3. Весьма сомнительно существование самостоятельного ледникового потока по понижению Чудского и Псковского озер. К сожалению, мелкомасштабность имеющихся снимков затрудняет детальное изучение района этой депрессии. Однако такое предположение имеет под собою реальную почву, ибо в пределах Псковско-Чудского понижения четко выраженные краевые образования отсутствуют. Это послужило поводом для произвольного проведения разными авторами стадиальных границ (Заррина, Краснов, 1965; Геоморфология и четвертичные отложения..., 1969; Раукас и др., 1971; и т. д.). Проанализировав рельеф Бежаницкой и соседних с ней возвышенностей, Л. М. Нерода (1974) также пришел к выводу об отсутствии Псковско-Чудского ледникового потока.

4. Сомнительна гипотеза о возникновении возвышенностей на стыке двух ледниковых потоков, во всяком случае это касается Хааньяской, 

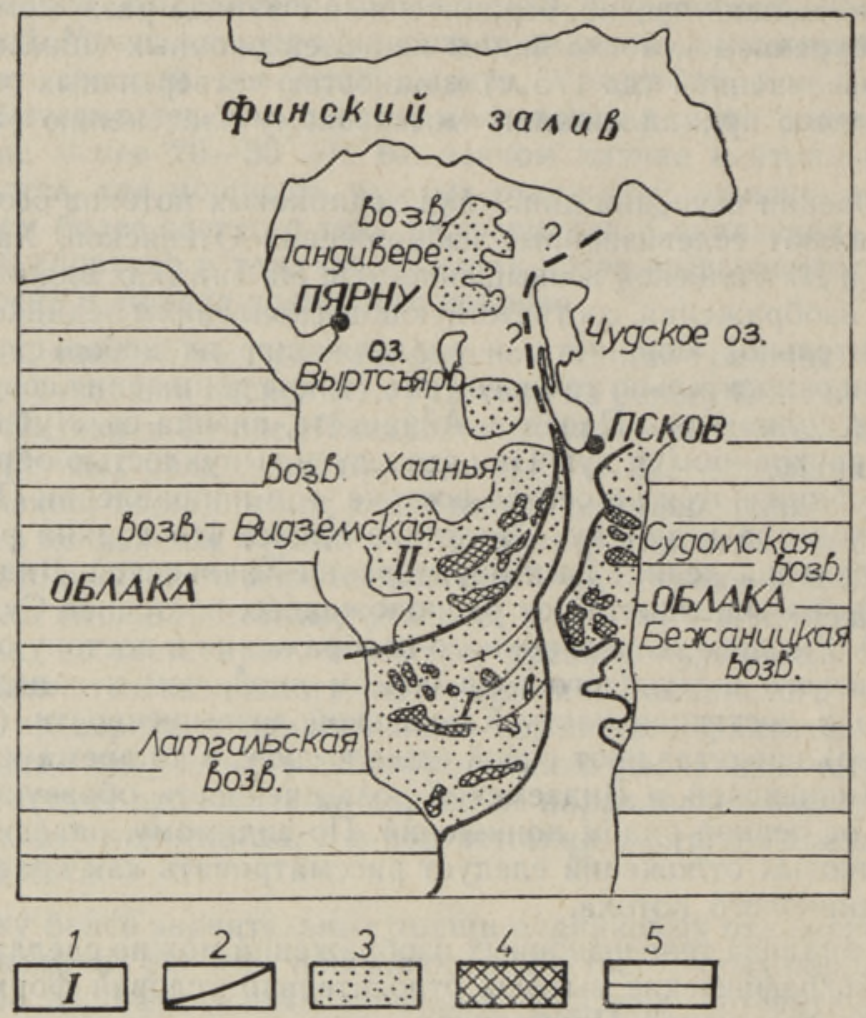

Схема предварительного дешифрирования телевизнонных снимков: 1 - стадии отступания ледника (по местному счету), 2 - гранищы стаднй, 3 - области мощной плейстоценовой аккумуляции, 4 - поннжения в пределах областей мощной аккумуляции, 5 - облака.

Видземской, Латгальской, Сакалаской, Отепяской и Пандивереской возвышенностей. По-видимому, все же решающую роль в первичном накоплении материала на месте будущей возвышенности играли неровности поверхности дочетвертичных пород (Можаев, 1973).

5. Необходимо пересмотреть представление об устойчивом ледоразделе плейстоценовых ледниковых потоков в Прибалтике, о чем уже высказывал мнение Л. М. Нерода (1974). Встает вопрос - не следует ли его проводить по понижению озер Чудского и Псковского, рассматривая две параллельные цепочки возвышенностей: Пандивереская Отепяская - Хааньяская - Латгальская, с одной стороны, и Лужская Судомская - Бежаницкая, с другой, как возникшие в краевых частях разных и, может быть, даже не строго синхронных ледниковых потоков Рижского и Ладожского. В таком случае граница максимального распространения ледникового потока Рижского залива на востоке должна проходить по линии: Латгальская возвышенность - восточная часть Хааньяской возвышенности (к востоку от долины р. Педедзе) - ? маргинальные камовые поля Сельгузе и Вазавере - камовое поле Авинурме - краевые образования Ийзаку - Иллука. Если обратиться к подробной характеристике перечисленных образований, данной коллегами из Эстонии (Раукас и др., 1971), то можно найти много конкретных фактов, говорящих в пользу высказанного предположения (ориенти- 
ровка отдельных форм рельефа и всех образований в целом, зональность их расположения, характер слагающих отложений и т. д.).

Изложенные выводы следует рассматривать только как рабочие гипотезы. Они нуждаются во всесторонней проверке. Однако из приведенных примеров ясно, что использование обладающих высокой обзорностью телевизионных снимков для изучения палеогеографии четвертичного периода в условиях Прибалтики позволяет если не решить, то по крайней мере поставить ряд интересных вопросов.

\section{ЛИТЕРАТУРА}

А с т а х о в В. И., Е р омен ко В. Я. 1974. Геологическая информативность телевизнонных космических снимков закрытых районов (на примере Приенисейской Сибири). Исследование природной среды космическими средствами. Геология и геоморфология, т. 2, M.

Б а ш и ло в а И. И. 1973. Использование телевизионных снимков, полученных с метеорологических спутников, для изучения геологического строения Земли. В кн.: Космическая иконика. М.

Б а ш и л о в а И. И., Е р е м и н В. К., М ахи и Г. В. 1973а. Космические телевизионные снимки как средство тектонического районирования крупных территорий и прогнозирования полезных ископаемых на примере Западно-Сибирской плиты и прилегающих районов. Исследование природной среды космическими средствами. Геология и геоморфология, т. $2, \mathrm{M}$.

Б аш и ло в а И. И., М ах ин Г. В., Е р е м и н В. К. 1973б. Исследование космических телевизионных снимков - средство тектонического районирования. Изв. вузов. Геол. и разведка, № 7.

еоморфология и четвертичные отложения Северо-Запада европейской части СССР (Ленинградская, Псковская и Новгородская области). 1969. K VIII конгрессу INQUA, Франция, 1969. Отв. ред. Д. Б. Малаховский, К. К. Марков. Л.

Г р и го р в в А. А. 1970 . Опыт геоморфологического и геологического дешифрирования космических фотографий Земли (на примере бассейна Тулароса, США). Изв. ВГО, 102, № 5 .

3 а р р и н а Е. П., К р а с н о в И. И. 1965. Проблема сопоставления поясов ледниковых краевых образований на Северо-Западе европейской части СССР и прилегающих зарубежных территорий. В кн.: Краевые образования материкового оледенения. Вильнюс.

М о ж а е в Б. Н. 1973. Новейшая тектоника Северо-Запада Русской равнины. Л.

Не род а Л. М. 1974. Рельеф и происхождение Бежаницкой возвышенности в системе островных массивов Северо-Запада Русской равнины. Вестник ЛГУ, № 24, геология и география, вып. 4.

Р а ук а с А. В., Р я Х н и Э. Э., М и йд е л А. М. 1971. Краевые ледниковые образования Северной Эстонии. Таллин.

У с и к о в а Т. В., М а л ах о в ски й Д. Б., Г а р б а р Д. И. 1970. Домикулинские озерные отложения северо-западного Приладожья. История озер. Тр. Всесоюз. симпоз., вып. 2, Вильнюс.

Лаборатория аэрометодов

Министерства геологии СССР
Поступила в редакцию

6/V 1976

\section{B. MOZAJEV, V. MOZAJEVA}

\section{KOSMOSETELEVISIOONI KASUTAMISEST BALTIMAADE LIUSTIKUSETETE KUJUNEMISE UURIMISEL}

Kasutatud on Maa tehiskaaslase vahendusel tehtud fotosid, millel on nähtavad üle $1250 \mathrm{~m}$ pikkused objektid. Televisioonivõtetel on eristatavad keskmisest paksemate liustikusetetega alad (kōrgustikud, mattunud orud), tektoonilised lōhed ja rikkevööndid (vt. joonis). Liustikusetete vööndilisuse alusel on vồimalik järeldada, et Peipsi-Pihkva jääkeelt ei ole eksisteerinud ning et Otepää, Haanja, Vidzeme ja Latgale kõrgustik on kujunenud aluspōhja tuumikul loodest liikunud liustiku toimel. 
B. MOZHAYEV, V. MOZHAYEVA

\section{AN ATTEMPT AT USING COSMIC TV PHOTOGRAPHY FOR THE STUDY OF THE FORMATION CONDITIONS OF GLACIAL DEPOSITS IN THE EASTERN BALTIC}

In the study, use was made of telecasts from a satellite, in which objects of a size exceeding $1250 \mathrm{~m}$ were discernible. On the grounds of telephotos it has been possible to examine areas of glacial deposits of a medium thickness (heights, buried valleys) and zones of tectonic joints (see the figure). On the basis of the zonality of glacial deposits it may be assumed that the Peipsi-Pihkva glacier tongue did not exist at all, and the Otepää, Haanja, Vidzeme, and Latgal heights were formed on the influence of the bedrock relief by the glacier moving from the NW. 